\title{
Riparian Ground Beetles (Coleoptera) on the Banks of Running and Standing Waters
}

\author{
Marina Kirichenko-Babko ${ }^{1, *}$, Yaroslav Danko ${ }^{2}$, Małgorzata Franus ${ }^{3}$, Witold Stępniewski ${ }^{4}$ \\ and Roman Babko ${ }^{1}$ \\ 1 Department of Invertebrate Fauna and Systematics, Schmalhausen Institute of Zoology NAS of Ukraine, \\ 01030 Kyiv, Ukraine; rbabko@ukr.net \\ 2 Faculty of Natural Sciences and Geography, Sumy Makarenko State Pedagogical University, \\ 40002 Sumy, Ukraine; yaroslavdanko@gmail.com \\ 3 Faculty of Civil Engineering and Architecture, Lublin University of Technology, 20-618 Lublin, Poland; \\ m.franus@pollub.pl \\ 4 Faculty of Environmental Engineering, Lublin University of Technology, 20-618 Lublin, Poland; \\ w.stepniewski@pollub.pl \\ * Correspondence: kirichenko@izan.kiev.ua
}

Received: 29 April 2020; Accepted: 19 June 2020; Published: 23 June 2020

\begin{abstract}
Rivers and their floodplains offer a wide variety of habitats for invertebrates. River ecosystems are subject to high anthropic influence: as a result the channel morphology is changed, swamps are drained, floodplains are built up, and rivers are polluted. All this has radically changed the environment for the inhabitants of the floodplains, including riparian stenotopic species. Although riparian arthropods are oriented primarily to the production of hydro-ecosystems, the type of water body-lentic or lotic_-has a determining effect in the structure of communities. Most riparian arthropods have evolutionarily adapted to riverbanks with significant areas of open alluvial banks. This paper considered the structure of assemblages of ground beetles associated with the riverbanks and the shores of floodplain lakes and their differences. The banks of rivers and the shores of floodplain lakes were considered separately due to the differences in the habitats associated with them. Our results showed that riverbanks, which experience significant pollution, were actively colonized by vegetation and were unsuitable for most riparian ground beetles. The shores of floodplain lakes, being an optional habitat for riparian arthropods, cannot serve as refugia. Thus, the transformation of floodplain landscapes and river pollution creates a problem for the biological diversity of floodplain ecosystems, since riparian stenotopic species of the riverbanks become rare and disappear.
\end{abstract}

Keywords: riverbanks; floodplain lakes; Carabidae; stenotopic species; assemblage; overgrown

\section{Introduction}

Rivers with their floodplains are some of the most diverse and biologically productive ecosystems on Earth [1,2]. At the same time, they are among the most vulnerable [3-5]. Unlike the seas and oceans, river ecosystems are highly dependent on the state of their floodplains. This dependence is magnified in small rivers.

The dependence of the water quality in rivers on the state of the floodplain ecosystems is obvious today. In the 20th century, rivers, having lost their function as suppliers of water and food (a civilizational function), were turned into objects for recreation and sport fishing, and became receptors of wastewater from enterprises and municipal treatment facilities. River valleys include residential areas, agricultural lands, and industrial enterprises.

Since the 1950s, as a result of drainage, a strong degradation of floodplain ecosystems, with loss of their characteristic mosaic of water and land habitats and a decrease in biodiversity, has been observed 
in Ukraine. Effluent has led to a drop in the water quality and an increase in the trophic status of most rivers, resulting in a significant decrease in their self-cleaning potential. River pollution has also promoted a change in the quality of the banks and overgrowth of vegetation.

A feature of intact lowland rivers is the presence of various coastal elements, with a significant part composed of open alluvial sandbars, constituting a unique biotope [6]. Over millions of years, wandering riverbeds, changing direction, left numerous meanders, which, over time, lost their connection with the channel, turning into floodplain lakes.

The banks of rivers and floodplain lakes are unique ecotones which form a complex gradient between aquatic and terrestrial ecosystems $[7,8]$. Ecotones in floodplains exist at the boundary between land and water, and between surface waters and groundwaters $[9,10]$. Unique communities are found on the banks of the rivers [11,12], the representatives of which are spatially limited by the shoreline and mainly trophically oriented to the production of the hydro-ecosystem [13-16]. Among riparian arthropods, ground beetles, staphylinids, and spiders have great species diversity [17-19]. Riparian arthropods are an important component of the diversity of floodplain ecosystems [20,21]. At the same time, most specialized riparian arthropods, unlike floodplain species, are unable to survive under the conditions of anthropically monotypic banks, which lack a habitat for riparian species, i.e., alluvial deposits. Since the end of the 1990s, regulation of river flows to increase the stability of bars has contributed to the succession of vegetation and has affected the communities of open sand sediments $[22,23]$. On anthropically altered rivers, many species, especially highly specialized ones, have become rare and disappeared in the absence of refugia. Since the end of the 1980s, there has been a significant reduction in the number of species typical of open riverbanks, some of which have become endangered in many European countries [24-27]. The changes caused by anthropic pressures on river ecosystems (water pollution, loss of riverine habitats) in many cases do not apply to floodplain lakes and oxbows. As a rule, wastewater is discharged mainly into flowing water bodies (rivers and streams), while the floodplain water bodies experience mainly recreational pressure and are rarely used for fish farming. This suggests that the shores of lakes could potentially act as refugia for riparian species.

Understanding how riparian species can adapt to different types of water bodies and their banks and shores, whether there are species common to the shorelines of riverbed and lakes (riparian and littoral zones), and whether riparian species can survive unfavorable periods on the littoral of lakes is important for conservation of biodiversity of the river valleys.

Most works to date are devoted to the study of the diversity of riparian arthropods of lowland and mountain rivers [16,28-33] and to the influence of changes in river hydrology on soil invertebrates [34-37], and little is known about the terrestrial fauna in the banks of stagnant water bodies [38-42].

In this study, using ground beetle assemblages, the following questions are addressed. The first relates to the extent to which banks of flowing and stagnant reservoirs of one flat river system differ in the composition and structure of the arthropod communities. The second is whether the shores (littoral) of floodplain lakes act as refugia for riparian species, i.e., whether they can preserve the diversity not only of floodplain species, but also of specialized riparian species.

\section{Materials and Methods}

\subsection{Study Area}

The study was conducted in a 80-km section of the Psel River (starting with Zapsillya), a first-order tributary of the Dnieper River, in the Sumy region (northeastern Ukraine, Figure 1). In the transverse profile of the studied section, alder forests grow on the wetlands situated near terraces, while oak forests, wet meadows, and riparian shrubs grow in the central part of the floodplain. There also are patches of artificial plantations: trees (birch, oak, pine) and shrubs (hazel, common ninebark). Part of the floodplain has been reclaimed and turned into meadows. 


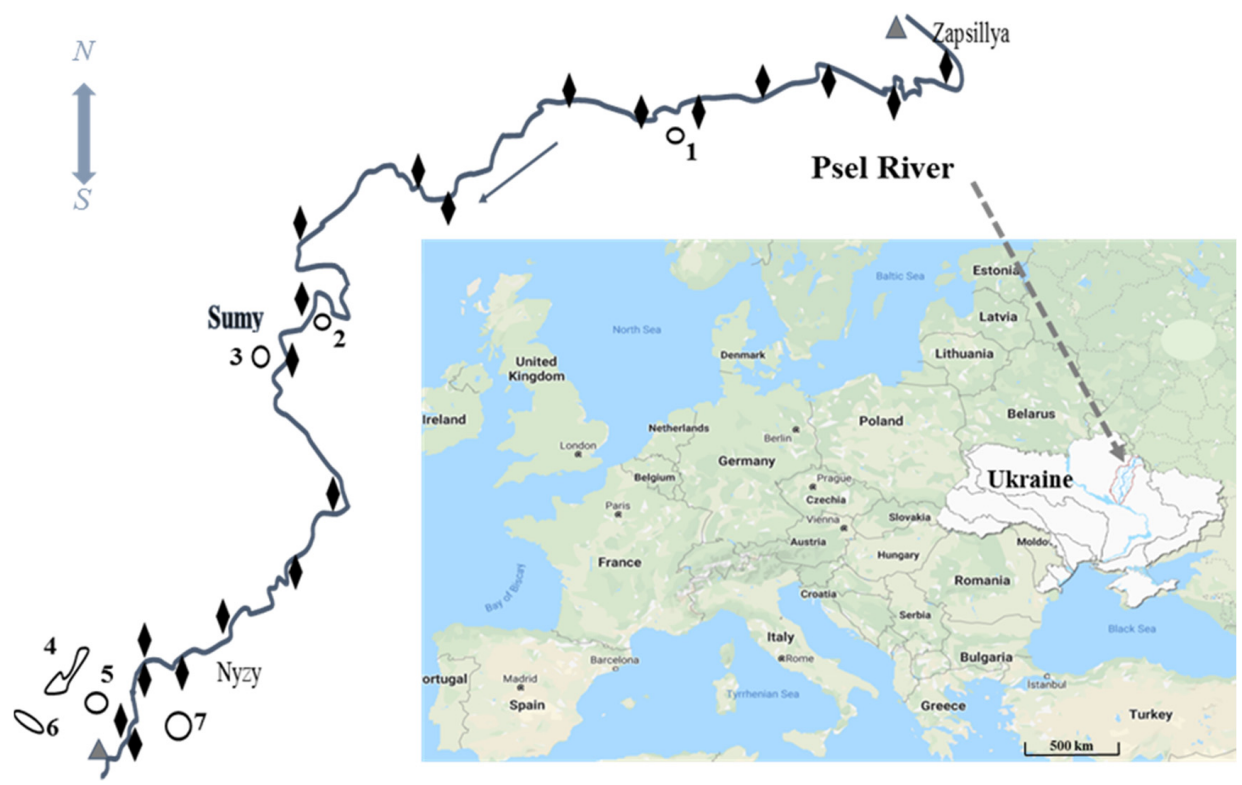

Figure 1. The study area, with the location of river stations (marked by black rhombs) and floodplain lakes (1-7) surveyed in the Psel River. The arrow indicates the river flow direction; the grey triangles are marked the study section; the dashed arrow shows the study area in the river basin of Psel.

The study included various habitats of the channel of the Psel River, covering the riverbed form units (open sand bars, referred to as exposed riverine sediments, ERS, by other researchers), which alternate with sections of the bank overgrown with different levels of vegetation (vegetated bars). A part of the open banks has been colonized by vegetation. At the same time, the open sandy riverbanks accounted about $40 \%$.

Considering the vegetation cover on sandy and silted riverbanks (or bars) as a gradient, the following three stages of overgrowth by vegetation were distinguished [43]: stage 1-appearance of small spots of higher aquatic vegetation along the shoreline and solitary land plants; stage 2-expansion of terrestrial grassy vegetation on the surface of the bank and plant coverage of about $50 \%$ of the shoreline; and stage 3-complete coverage of the surface of the bank by grassy and woody-shrubby vegetation and almost complete separation of the dry land from the shoreline by the higher aquatic vegetation (Figure 2).

The choice of stations along the river was determined by the presence open bars and banks with varying degrees of vegetation coverage development. Accordingly, the distances between the 20 stations on the riverbanks (Figure 1) were not equal, ranging from 5 to $20 \mathrm{~km}$.

The floodplain lakes under study are separate from the riverbed by different distances-from 100 to $300 \mathrm{~m}$ (Figure 1). These lakes are either mesotrophic or eutrophic and are 1.5 to $7 \mathrm{~m}$ deep. The lakes shores are mostly covered with vegetation and the few sections of the open shore are either silted alluvial sediments or alluvium covered with a layer of plant debris. The shores of oxbow lakes were analyzed in terms of their openness/closeness and categorized into shores overgrown with meadow hygrophytic vegetation (opened habitats) and those with trees and shrubs (closed).

Thus, the banks of the riverbed at different stages of vegetation cover development and the shores of floodplain lakes (opened and closed) were considered as separate types of habitats. 


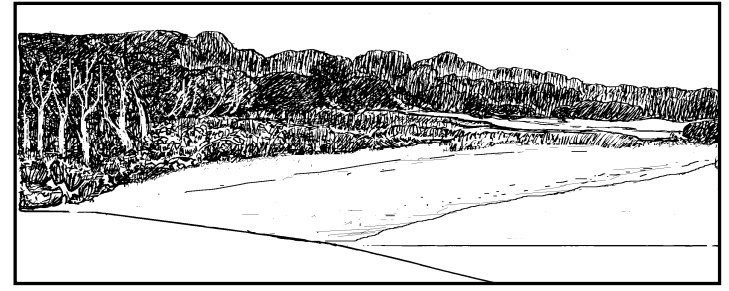

(a)

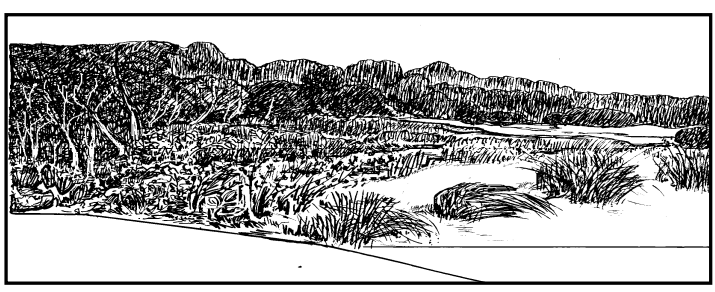

(c)

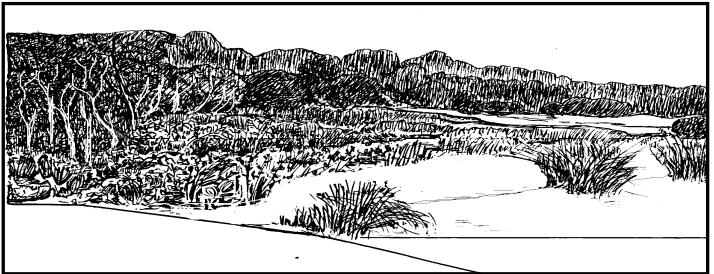

(b)

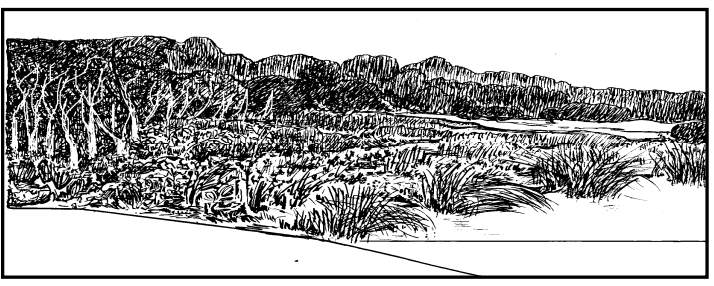

(d)

Figure 2. A graphical representation of the stages of overgrowth by vegetation of open alluvial bars along the riverbanks: (a) open sand bar (ob), (b) stage 1 (os1), (c) stage 2 (os2), and (d) stage 3 (os3) of overgrowth.

\subsection{Sampling Methods}

Sampling was conducted from April to October in 2008-2010 at 27 stations, with 20 along the banks of the river and 7 in the shores of the floodplain lakes. The beetles were collected using pitfall traps with 0.3-L plastic cups (diameter $7.2 \mathrm{~cm}$ ) partly filled with a preserving solution. The traps were set parallel to the shoreline: 15 traps in three rows in accordance with the width of each station. Samples were collected 7 days after the installation of the trap, twice a month.

Carabid beetles were identified to the species level $[44,45]$. The species were classified as "riparian" based on the previous studies [43]. The concept of riparian, as used here, means that the species mainly or exclusively occurs in riverbanks with open riverine sediments [20,46]. The groups of species associated with the floodplain and the shores of floodplain lakes were also distinguished.

\subsection{Data Analysis}

A matrix containing the data on the abundance of 95 species of ground beetles in the 27 stations studied was used for analysis. The abundance for each species was averaged over habitats and years to obtain the average statistical density of each population.

Non-metric multidimensional scaling (NMDS) was used to uncover variation in beetle assemblages among stations and habitats and to analyze the patterns of the spatial distribution of ground beetles across the floodplain Psel River. This method is especially suitable for environmental data [47-50]. The Kulczynski distance was used, because it has shown good results in the biological and environmental applications [51-55]. The data on ground beetles abundances were Hellinger-transformed. The data analysis was performed in $\mathrm{R}$ through the core and vegan packages [56]. The results were plotted through the ggplot2 package [57].

\section{Results}

During the study period, a total of 95 species of ground beetles from 32 genera were recorded (Table 1). The largest numbers of species were found for the genera Bembidion (21 species), Pterostichus (9), Agonum (7), Dyschirius (5), and Badister (5). In overall, 81 species were recorded on the banks of the river and 51 species on the shores of floodplain lakes. Moreover, 36 species ( $38 \%$ of the total number of species) were found in both types of habitats. 
Table 1. Ground beetles species caught on the banks of the river Psel and the shores of floodplain lakes, with their frequencies of occurrence (\%) in the habitats and codes. Species are grouped according to their habitat requirements. rip: riparian, lit: littoral.

\begin{tabular}{|c|c|c|c|c|c|c|}
\hline \multirow{2}{*}{\multicolumn{2}{|c|}{ Species and Their Codes }} & \multicolumn{2}{|c|}{ River Banks } & \multicolumn{2}{|c|}{ Shores of Lakes } & \multirow{3}{*}{$\begin{array}{c}\begin{array}{c}\text { Habitat } \\
\text { Requirements }\end{array} \\
\text { rip }\end{array}$} \\
\hline & & \multirow{2}{*}{$\begin{array}{c}\text { Open Bars } \\
-\end{array}$} & \multirow{2}{*}{$\begin{array}{c}\begin{array}{c}\text { Stages 1-3, } \\
\text { Backwaters }\end{array} \\
100\end{array}$} & \multirow{2}{*}{$\begin{array}{c}\text { Open } \\
-\end{array}$} & \multirow{2}{*}{$\begin{array}{c}\text { Closed } \\
-\end{array}$} & \\
\hline Agonum impressum & Ag.impr & & & & & \\
\hline Asaphidion flavipes & As.flav & 22.1 & 77.4 & - & 0.5 & rip \\
\hline Bembidion argenteolum & Be.arge & 100 & - & - & - & rip \\
\hline Bembidion azurescens & Be.azur & 55.7 & 44.3 & - & - & rip \\
\hline Bembidion cruciatum & Be.andr & 100 & - & - & - & rip \\
\hline Bembidion femoratum & Be.femo & 86.8 & 13.2 & - & - & rip \\
\hline Bembidion laticolle & Be.lati & 100 & - & - & - & rip \\
\hline Bembidion litorale & Be.lito & 96.5 & 3.5 & - & - & rip \\
\hline Bembidion ruficolle & Be.rufi & 100 & - & - & - & rip \\
\hline Bembidion semipunctatum & Be.semi & 66.7 & 33.3 & - & - & rip \\
\hline Bembidion tenellum & Be.tene & 25.0 & 75.0 & - & - & rip \\
\hline Bembidion tetracolum & Be.tetr & 43.4 & 54.1 & - & 2.4 & rip \\
\hline Bembidion varium & Be.vari & 73.1 & 27.7 & - & 0.9 & rip \\
\hline Chlaenius nitidulus & Ch.niti & 43. & 57 & - & - & rip \\
\hline Cicindela hybrida & Ci.hybr & - & 100 & - & - & rip \\
\hline Dyschirius aeneus & Dy.aene & 7.3 & 53.3 & 39.5 & - & rip \\
\hline Dyschirius arenosus & Dy.aren & 82.5 & 16.7 & - & 0.8 & rip \\
\hline Dyschirius neresheimeri & Dy.nere & 100 & - & - & - & rip \\
\hline Dyschirius nitidus & Dy.niti & 72.7 & 27.3 & - & - & rip \\
\hline Elaphrus riparius & El.ripa & 75.6 & 24.4 & - & - & rip \\
\hline Omophron limbatum & Om.limb & 65.4 & 34.6 & - & - & rip \\
\hline Badister dilatatus & Ba.dila & - & - & - & 100 & lit \\
\hline Badister peltatus & Ba.pelt & - & 47.3 & 29.5 & 23.2 & lit \\
\hline Badister sodalis & Ba.soda & - & - & - & 100 & lit \\
\hline Bembidion assimile & Be.assi & 1.1 & 7.1 & 85.6 & 6.1 & lit \\
\hline Bembidion biguttatum & Be.bigu & 0.7 & 6.7 & - & 92.6 & lit \\
\hline Bembidion dentellum & Be.dent & 10.6 & 9.2 & - & 80.2 & lit \\
\hline Bembidion doris & Be.dori & 11.4 & 13.6 & 49.2 & 25.8 & lit \\
\hline Elaphrus cupreus & El.cupr & 9.2 & 6.9 & 20.6 & 63.3 & lit \\
\hline Philorhizus spilotus & Ph.spil & - & - & - & 100 & lit \\
\hline Stenolophus skrimshiranus & St.skri & - & - & 66.7 & 33.3 & lit \\
\hline Abax parallelopipedus & Ab.ater & - & 59.0 & - & 41.0 & \\
\hline Abax parallelus & Ab.para & - & 19.4 & - & 80.6 & \\
\hline Acupalpus flavicollis & Ac.flav & 31.0 & 69.0 & - & - & \\
\hline Agonum duftschmidi & Ag.duft & - & 100 & - & - & \\
\hline Agonum fuliginosum & Ag.fuli & 1.8 & 2.3 & 19.2 & 76.7 & \\
\hline Agonum moestum & Ag.moes & - & 23.1 & - & 76.9 & \\
\hline Agonum sexpunctatum & Ag.sexp & - & 100 & - & - & \\
\hline Agonum versutum & Ag.vers & 100 & - & - & - & \\
\hline Agonum viduum & Ag.vidu & - & 100 & - & - & \\
\hline Amara communis & Am.comm & - & 48.7 & 51.3 & - & \\
\hline Amara eurynota & Am.eury & - & 100 & - & - & \\
\hline Amara ovata & Am.ovat & - & 21.1 & - & 78.9 & \\
\hline
\end{tabular}


Table 1. Cont

\begin{tabular}{|c|c|c|c|c|c|c|}
\hline \multirow{2}{*}{\multicolumn{2}{|c|}{ Species and Their Codes }} & \multicolumn{2}{|c|}{ River Banks } & \multicolumn{2}{|c|}{ Shores of Lakes } & \multirow{3}{*}{$\begin{array}{c}\text { Habitat } \\
\text { Requirements }\end{array}$} \\
\hline & & \multirow{2}{*}{$\begin{array}{c}\text { Open Bars } \\
-\end{array}$} & \multirow{2}{*}{$\begin{array}{r}\begin{array}{r}\text { Stages 1-3, } \\
\text { Backwaters }\end{array} \\
-\end{array}$} & \multirow{2}{*}{$\begin{array}{c}\text { Open } \\
100\end{array}$} & \multirow{2}{*}{$\begin{array}{c}\text { Closed } \\
-\end{array}$} & \\
\hline Anisodactylus binotatus & An.bino & & & & & \\
\hline Anisodactylus nemorivagus & An.nemo & - & - & 100 & - & \\
\hline Anisodactylus signatus & An.sign & - & 100 & - & - & \\
\hline Anthracus consputus & An.cons & 47.8 & 52.2 & - & - & \\
\hline Badister bullatus & Ba.bull & - & 62.7 & - & 37.3 & \\
\hline Badister unipustulatus & Ba.unip & - & - & - & 100 & \\
\hline Bembidion articulatum & Be.arti & 45.1 & 30.3 & 23.8 & 0.7 & \\
\hline Bembidion lampros & Be.lamp & 33.9 & 66.1 & - & - & \\
\hline Bembidion octomaculatum & Be.octo & 26.4 & 73.6 & - & - & \\
\hline Bembidion obliquum & Be.obli & 100 & - & - & - & \\
\hline Bembidion properans & Be.prop & - & 100 & - & - & \\
\hline Bembidion quadrimaculatum & Be.quad & 23.5 & 76.5 & - & - & \\
\hline Blemus discus & Bl.disc & 37.2 & 62.8 & - & - & \\
\hline Broscus cephalotes & Br.ceph & - & - & - & 100 & \\
\hline Carabus cancellatus & Ca.canc & - & 100 & - & - & \\
\hline Carabus convexus & Ca.conv & - & 100 & - & - & \\
\hline Carabus granulatus & Ca.gran & - & 51.6 & 13.3 & 35.1 & \\
\hline Carabus menetriesi & Ca.mene & - & 100 & - & - & \\
\hline Chlaenius nigricornis & Ch.nigr & 89.6 & 10.4 & - & - & \\
\hline Chlaenius vestitus & Ch.vest & 34.7 & 65.3 & - & - & \\
\hline Clivina collaris & Cl.coll & - & 100 & - & - & \\
\hline Clivina fossor & Cl.foss & 41.1 & 38.4 & - & 20.5 & \\
\hline Cymindis axillaris & Cy.axil & - & - & 100 & - & \\
\hline Dyschiriodes globosus & Dy.glob & 23.0 & 23.5 & 6.0 & 47.6 & \\
\hline Epaphius secalis & Ep.seca & 2.0 & 10.9 & - & 87.1 & \\
\hline Harpalus affinis & Ha.affi & 50 & 50 & - & - & \\
\hline Harpalus distinguendus & Ha.dist & - & 100 & - & - & \\
\hline Leistus terminatus & Le.term & - & 100 & - & - & \\
\hline Loricera pilicornis & Lo.pili & - & 18.0 & 51.3 & 30.8 & \\
\hline Notiophilus palustris & No.palu & - & 100 & - & - & \\
\hline Oodes gracilis & Oo.grac & - & - & - & 100 & \\
\hline Oodes helopioides & Oo.helo & 1.0 & 8.3 & 70.3 & 20.4 & \\
\hline Oxypselaphus obscurum & Ox.obsc & - & 100 & - & - & \\
\hline Panagaeus bipustulatus & Pa.bipu & - & - & - & 100 & \\
\hline Panagaeus cruxmajor & Pa.crux & - & 30.9 & 27.6 & 41.4 & \\
\hline Patrobus atrorufus & Pa.atro & - & - & - & 100 & \\
\hline Poecilus cupreus & Po.cupr & 100 & - & - & - & \\
\hline Platynus assimile & Pl.assi & 4.4 & 64.0 & 3.5 & 32.5 & \\
\hline Pterostichus anthracinus & Pt.anth & 8.9 & 23.0 & 14.7 & 53.4 & \\
\hline Pterostichus gracilis & Pt.grac & - & - & - & 100 & \\
\hline Pterostichus melanarius & Pt.mela & - & 69.2 & - & 30.8 & \\
\hline Pterostichus minor & Pt.mino & 5.0 & 17.0 & 52.6 & 25.3 & \\
\hline Pterostichus niger & Pt.nige & 1.7 & 98.3 & - & - & \\
\hline Pterostichus nigrita & Pt.nigr & 1.4 & 17.2 & 32.4 & 50.0 & \\
\hline Pterostichus oblongopunctatus & Pt.oblo & 1.8 & 59.4 & - & 39.8 & \\
\hline Pterostichus strenuus & Pt.stre & 5.8 & 72.6 & - & 21.6 & \\
\hline
\end{tabular}


Table 1. Cont.

\begin{tabular}{|c|c|c|c|c|c|c|}
\hline \multirow{2}{*}{\multicolumn{2}{|c|}{ Species and Their Codes }} & \multicolumn{2}{|c|}{ River Banks } & \multicolumn{2}{|c|}{ Shores of Lakes } & \multirow{2}{*}{$\begin{array}{c}\text { Habitat } \\
\text { Requirements }\end{array}$} \\
\hline & & Open Bars & $\begin{array}{l}\text { Stages 1-3, } \\
\text { Backwaters }\end{array}$ & Open & Closed & \\
\hline Pterostichus vernalis & Pt.vern & - & 15.6 & - & 84.4 & \\
\hline Stenolophus mixtus & St.mixt & 11.2 & 13.8 & 75.0 & - & \\
\hline Stenolophus teutonus & St.teut & 54.5 & - & - & 45.5 & \\
\hline Trechus quadristriatus & Tr.quad & - & - & - & 100 & \\
\hline Trichocellus placidus & Di.plac & - & 100 & - & - & \\
\hline Trichocellus rufithorax & Di.rufi & - & 100 & - & - & \\
\hline
\end{tabular}

The NMDS on the abundances of ground beetles among stations showed major differences between assemblages in the banks of the river and in the shores of the floodplain lakes (Figure 3). It also highlighted that the conditions in the backwaters of the river, where the flow rate is slowed down and the substrate is silted, are close to those on the shores of lakes.

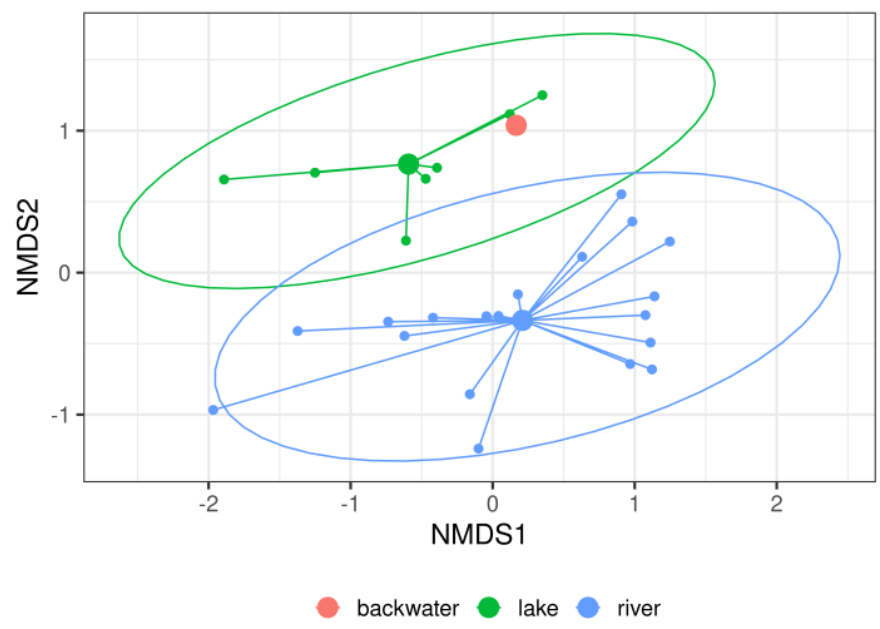

Figure 3. Non-metric multidimensional scaling (NMDS) of the Kulczynski distance matrix among ground beetle assemblages on the banks of the Psel River, backwater, and shores of floodplain lakes.

NMDS showed considerable variation between the shores of floodplain lakes (Figure 4, in the upper left quarter of the graph) and the habitats along the riverbanks (in the lower right part of the graph), with riverbanks completely covered by vegetation laying between them (Figure 4, os3). Indeed, the assemblage structure of ground beetles along the banks of the river and floodplain lakes is significantly different (Figure 5).

NMDS confirmed that the shores of floodplain lakes clearly differed in the composition of ground beetles from the banks of the channel (Figure 6). Open alluvial banks and sections of the banks with vegetation in the first and second stages of overgrowth were similar in composition. Overgrown riverbanks (stage 3) occupied an intermediate position, while both open and closed habitats on the shores of floodplain lakes are located in the left upper part of the plot (Figure 6).

The riparian and littoral species are represented in variable numbers on the banks of the Psel river and the shores of floodplain lakes (Figure 7). On the banks of the river, 21 riparian species were recorded (22\% of the total number of species), of which only five species were found on the banks of floodplain lakes: Asaphidion flavipes, Bembidion tetracolum, Bembidion varium, Dyschirius aeneus, Dyschirius arenosus (Table 1, Figure 7). Of the 10 littoral species found on the littoral of lakes, six were found in the riverbanks, but in a smaller abundance: Badister peltatus, Bembidion assimile, Bembidion biguttatum, Bembidion dentellum, Bembidion doris, and Elaphrus cupreus (Figure 7). 


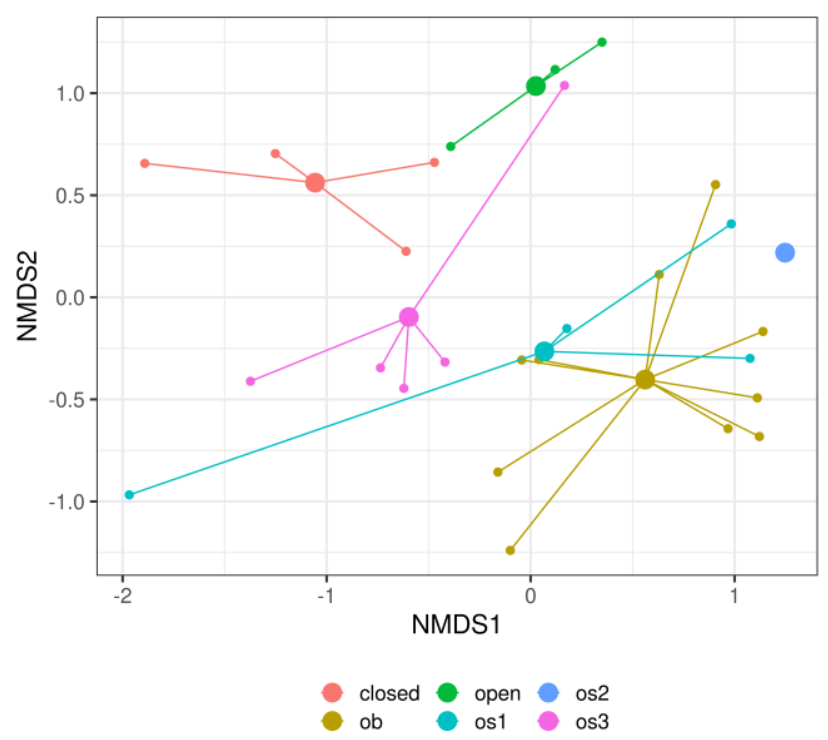

Figure 4. NMDS of the Kulczynski distance matrix among habitats located on the Psel riverbanks and oxbow lakes, classified according to plant overgrowth. ob, os1-3: as in Figure 2, open: shores of lakes with meadow vegetation, closed: shores of lakes covered with trees and shrubs.

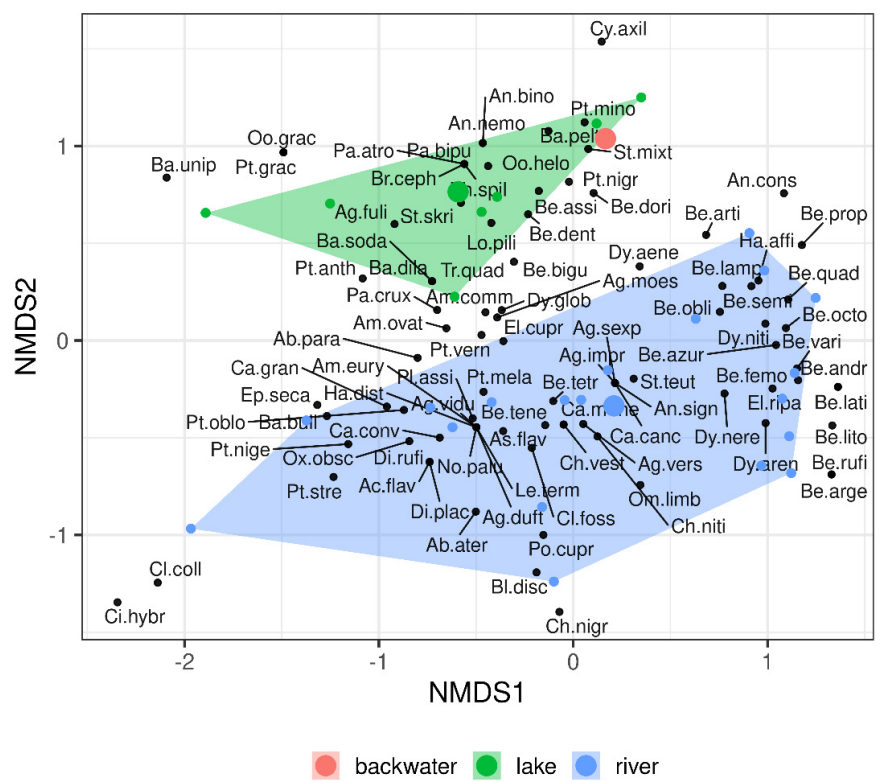

Figure 5. Species superimposed on the NMDS plain of the Kulczynski distance matrix among stations located on the riverbanks of the Psel, the shores of lakes, and in backwaters. Code abbreviations of the species are presented in Table 1.

The proportion of riparian and littoral species in the various habitats of riverbanks and shore lakes is significantly different. The proportion of specialized riparian species decreased in succession from the open banks of the river through the three stages of their overgrowth and to the shores of floodplain lakes (Figure 8). Littoral species prevailed in the shores of lakes, but showed tolerance to habitats on the banks of the river (Figure 8). The abundance of riparian species clearly decreased on the shores of floodplain lakes, while that of the littoral species decreased on the open riverbanks (Figure 9). 


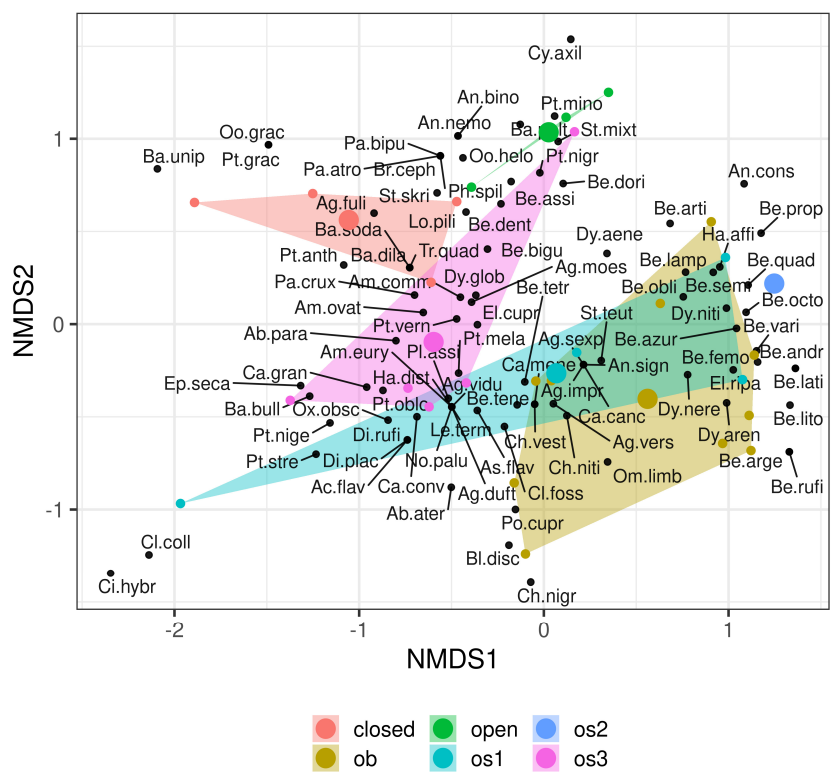

Figure 6. Species superimposed on the NMDS plain of the Kulczynski distance matrix among habitats located on the riverbanks of the Psel, oxbow lakes, and backwaters, classified according to vegetation overgrowth (as in Figures 2 and 4). Code abbreviations of the species are given in Table 1.

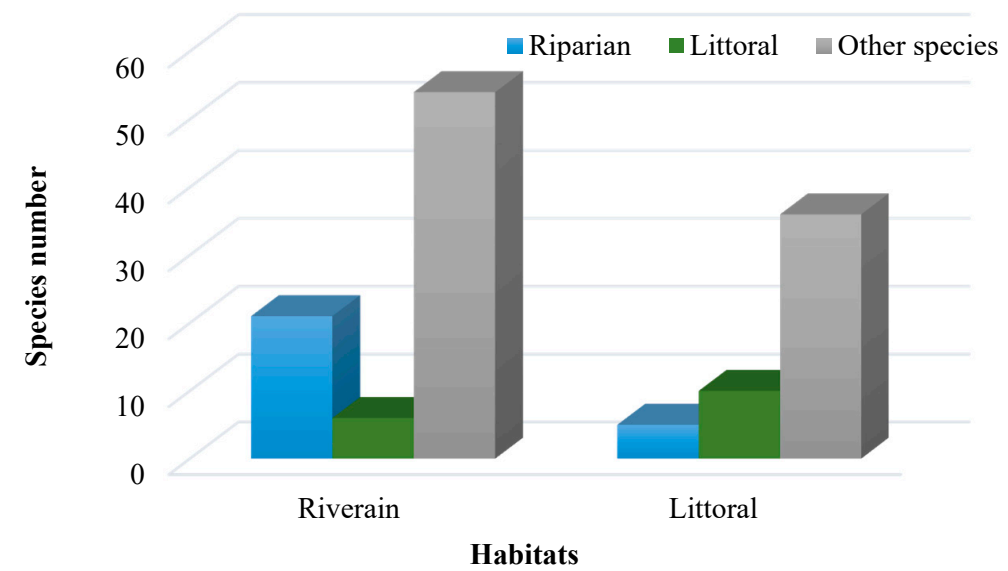

Figure 7. Number of riparian, littoral, and other species on the banks of the Psel River and the shores of floodplain lakes.

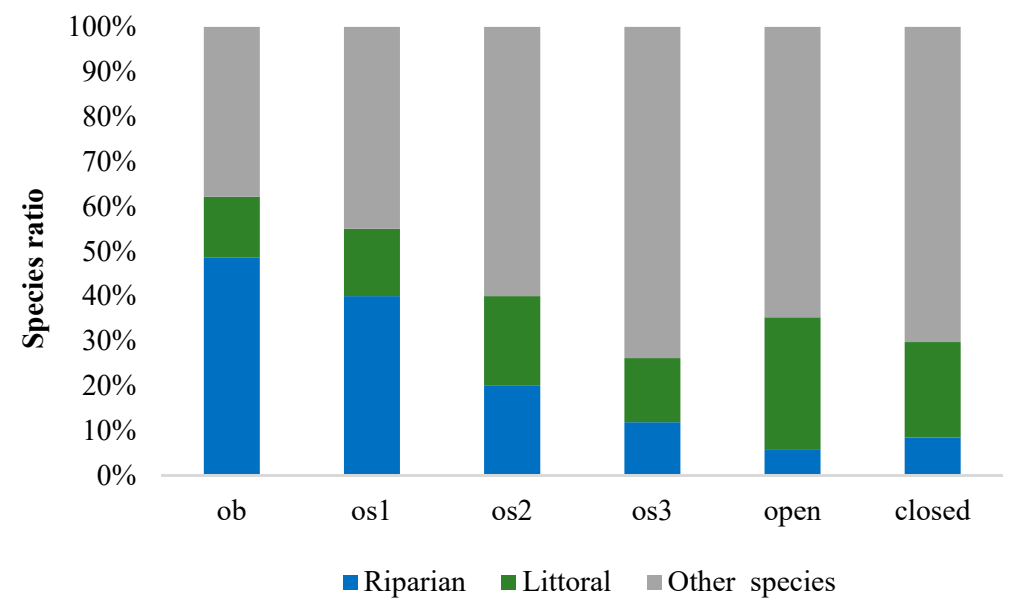

Figure 8. The proportion of riparian, littoral, and other species in the habitats of the Psel river and floodplain lakes. ob, os1-3, open, closed as in Figures 2 and 4. 


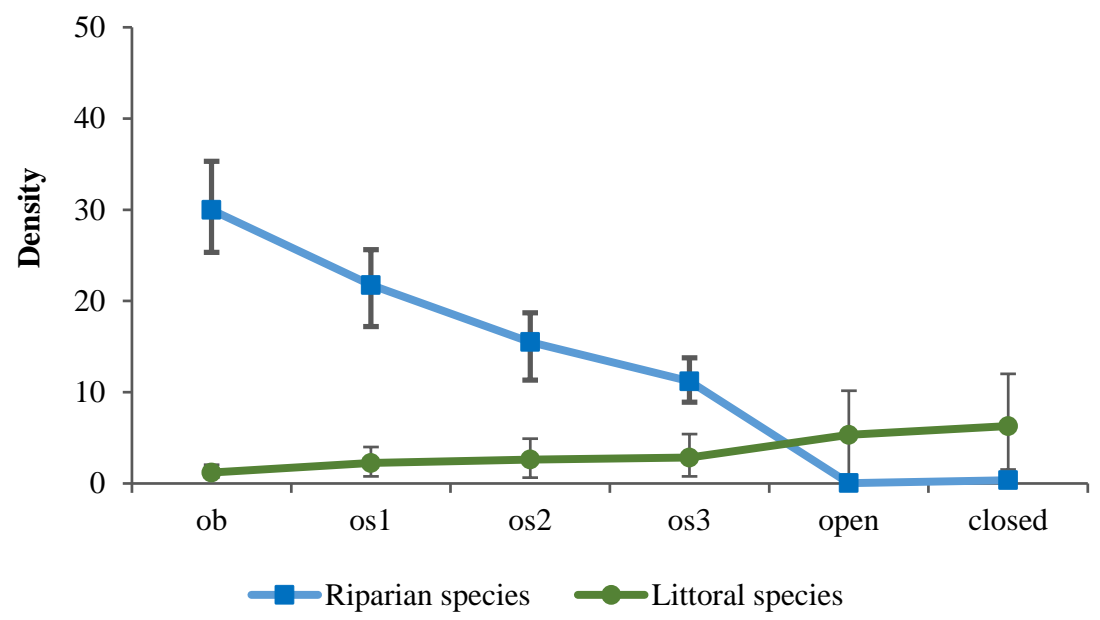

Figure 9. Density of populations of riparian and littoral species in open bars and the stages of vegetation overgrowth of the Psel riverbanks and the shores of floodplain lakes. ob, os1-3, open, closed as in Figures 2 and 4.

\section{Discussion}

Due to the constant drift of river channels within their floodplains, the landscape of river valleys is highly dynamic. The main factor determining the dynamics of channel processes and the transformation of shorelines is flood [58,59]. Flooding, regularly repeated on a geological time scale, constantly changes the configuration of the main elements of floodplains. The meanders provide a multitude of habitats that support multiple species with variable life strategies. The diversity of species along riverbanks is associated with a mosaic of habitats [60]. Fragmentation of the habitat also determines the structural organization of beetle assemblages, which usually show a spotted structure [35,61].

Despite the fact that the riparian species are focused on the production of hydroecosystems $[13,15,62]$, and floodplain water bodies, especially shallow ones, are highly productive ecosystems, the structure of the ground beetle assemblages on the banks is determined not so much by the presence of food objects, but by the type (lotic or lentic) and the quality of habitats.

Among the riparian species, a highly specialized group (stenotopic) stands out as adapted to the conditions of river banks $[17,20,43,46,63-65]$. The riparian species are mainly winged forms that can spread along the river, small in size and with a flattened body [16,66-68].

According to the NMDS results, the banks of the river and the shores of the floodplain lakes clearly differ in the species composition of ground beetles (Figures 5 and 6 ). The assemblage of ground beetles on the banks of the Psel river contains 21 riparian species (Table 1). Among them, 11 species of the genus Bembidion predominate, as also noted by other researchers $[36,68,69]$. Specifically, in the open banks on the flat Hase River (Germany) 12 stenotopic species were noted [39], nine of which were also recorded on the open banks of the Psel River: Asaphidion flavipes, Elaphrus riparius, Bembidion articulatum, Bembidion femoratum, Bembidion litorale, B. varium, Dyschirius arenosus, D. aeneus, and Omophron limbatum.

Many researchers have noted that riparian species are good indicators of habitat quality and particularly in the structure and quality of alluvial sediments [70,71]. For example, E. riparius and Bembidion semipunctatum are indicators for sand bars less covered by vegetation, unvegetated, or with mud; Dyschirius thoracicus and Bembidion litorale are indicators for open sand bars; and Bembidion cruciatum and B. femoratum are characteristic of less vegetated or unvegetated cobble, gravel, and sand bars [71].

Hydrotechnical transformations of riverbeds and allochthonous organic and inorganic pollution significantly increased the trophic status of most rivers and triggered plant coverage development on the earlier open river sediments. These phenomena have become global. The above factors and the lack of floods lead to development of monotypic conditions along the river banks, which, in turn, lead to changes in the structure of ground beetle communities $[27,72,73]$. Most researchers confirm a 
significant reduction in the number of riparian species $[22,23,39,74]$, many of which are classified as endangered [20,24-27].

As our results have shown, the expansion of vegetation on the open banks of the river significantly affects the species composition and spatial distribution of the riparian ground beetles (Figure 6). The number and density of riparian species decreases with increasing development of the vegetation cover (Figures 8 and 9).

Among 21 riparian species recorded on the banks of the Psel river, only A. flavipes, D. arenosus, $D$. aeneus, $B$. tetracolum, and $B$. varium tend to spread to the littoral of floodplain lakes. This ability has also been noted for E. riparius, Bembidion articulatum, and O. limbatum, which actively inhabited the open shores of the floodplain lake after its connection with the river was restored [39]. This is important and confirms the tolerance of these species to the conditions of floodplain water bodies.

Most studies distinguish a group of riparian species, the composition of which varies depending on the quality of the banks and the type of river (plain or mountain). There are few studies on species that prefer stagnant water bodies $[38,40,41]$ and analyzing arthropods of river banks and their floodplain lakes in comparative way [39,42,61]. For example, Šustek [42], studying the banks of the Danube and Morava rivers and their lakes, identified 21 ripal species of ground beetles (pp. 136-138), but analyzed their preference for the banks of standing and flowing water. Indeed, the author exclusively analyzed the banks with thickets of Phragmites australis, which predetermined the low number of riparian species recorded [42].

During our research, 51 species of ground beetles were recorded on the banks of the floodplain lakes of the Psel river, among which 10 preferred the banks of floodplain lakes (Table 1). The littoral species identified by us were also noted on different types of shores of the floodplain lakes of the Dnieper [40]. Apparently, the possibilities of riparian and littoral species spreading beyond the floodplain are limited. According to Lott [38], no riparian species were recorded on the shore of the studied ponds in England, with the exception of the littoral species Badister dilatatus.

Thus, most riparian species are associated with the open banks of flowing water bodies, which makes them extremely vulnerable in the rivers with channels changed by man and lacking their natural characteristics. Riparian species of riverbanks are as a rule not found on the banks of floodplain lakes. They are also rare in the sections of river where riverbank sediments are covered with vegetation. A number of species tolerant to overgrowth, for example, A. flavipes, E. riparius, B. articulatum, B. tetracolum, B. varium, D. arenosus, and D. aeneus, are also found on the banks of lakes, especially if they are situated close to the river bed $[39,61,75,76]$. Obviously, these species use the shores of floodplain lakes as fodder areas. However, the shores of lakes for them are not fully adequate habitats.

\section{Conclusions}

The banks of rivers and floodplain lakes are different habitats, and different assemblages of ground beetles are formed within them. A total of 95 species of ground beetles were found, of which 81 species were found on the riverbanks of the Psel and 51 species were found on the shores of floodplain lakes. Based on the analysis of their spatial distribution, 21 species that prefer the riverbanks and 10 species that prefer the shores of lakes were identified.

Our findings confirm that typically riparian species are associated with open riverbanks, though some species also occurred on the shores of floodplain lakes. Changes in the quality of banks and overgrowth with vegetation due to river pollution leads to a critical reduction in the habitat of riparian species, making them extremely vulnerable. Moreover, since the shores of the floodplain water bodies are only an optional habitat for a sub-set of species, they cannot be considered as refugia for riparian ground beetles. This should be taken into account when developing measures for the renaturalization of rivers and their banks. 
Author Contributions: Conceptualization, M.K.-B., R.B.; methodology, M.K.-B., R.B.; software and validation Y.D., R.B.; formal analysis, R.B., M.K.-B.; investigation, M.K.-B., R.B.; resources, M.K.-B., R.B.; data curation, M.K.-B., R.B.; writing-original draft preparation, M.K.-B., R.B., and Y.D.; writing-review and editing, M.K.-B., R.B., Y.D., M.F. and W.S.; visualization, M.K.-B., R.B., and Y.D.; supervision, M.K.-B., R.B. All authors have read and agreed to the published version of the manuscript.

Funding: This work was financially supported by National Academy of Science of Ukraine and Ministry of Science and Higher Education in Poland, within the statutory research of particular scientific units under subvention for science program.

Acknowledgments: The authors are much obliged to two anonymous reviewers for very valuable comments and linguistic revision of the manuscript.

Conflicts of Interest: The authors declare no conflict of interest.

\section{References}

1. Petts, G.E.; Amoros, C. (Eds.) Fluvial Hydrosystems; Chapman and Hall: London, UK, 1996.

2. Robinson, D.T.; Tockner, K.; Wad, J.V. The fauna of dynamic riverine landscapes. Freshw. Biol. 2002, 47, 661-677. [CrossRef]

3. Ward, J.V. Riverine landscapes: Biodiversity patterns, disturbance regimes, and aquatic conservation. Biol. Conserv. 1998, 83, 269-278. [CrossRef]

4. Naiman, R.J.; Décamps, H.; McClain, M.E. Riparia: Ecology, Conservation, and Management of Streamside Communities; Elsevier Academic Press Inc.: Cambridge, MA, USA, 2005.

5. Sabo, J.L.; Sponseller, R.; Dixon, M.; Gade, K.; Harms, T.; Heffernan, J.; Jani, A.; Katz, G.; Soykan, C.; Watts, J.; et al. Riparian zones increase regional species richness by harboring different, not more, species. Ecology 2005, 86, 56-62. [CrossRef]

6. UNECE. River Convention. In Convention on the Protection and Use of Transboundary Watercourses and International Lakes; Vlaams Parlement, Stuk 263 (No. 1); United Nations Economic Commission for Europe Geneva: Genève, Switzerland, 1992.

7. Ward, J.V.; Tockner, K.; Schiemer, F. Biodiversity of floodplain river ecosystems: Ecotones and connectivity. Regul. Rivers Res. Mgmt. 1999, 15, 125-139. [CrossRef]

8. Boscaini, A.; Franceschini, A.; Maiolini, B. River ecotones: Carabid beetles as a tool for quality assessment. Hydrobiologia 2000, 422, 173-181. [CrossRef]

9. Naiman, R.J.; Décamps, H. (Eds.) The Ecology and Management of Aquatic Terrestrial Ecotones; Pearl River: New York, NY, USA; Parthenon, Greece, 1990.

10. Ward, J.V.; Wiens, J.A. Ecotones of riverine ecosystems: Role and typology, spatio-temporal dynamics, and river regulation. In Fish and Land/Inland Water Ecotones-The Need for Integration of Fisheries Science, Limnology and Landscape Ecology; Zalewski, M., Thorpe, J.E., Schiemer, F., Eds.; Pearl River: New York, NY, USA; Parthenon, Greece, 1999.

11. Ballinger, A.; Mac Nally, R.; Lake, P.S. Immediate and longer-term effects of managed flooding on floodplain invertebrate assemblages is south-eastern Australia: Generation and maintenance of a mosaic landscape. Freshw. Biol. 2005, 50, 1190-12025. [CrossRef]

12. Stanford, J.A.; Lorang, M.S.; Hauer, F.R. The shifting habitat mosaic of river ecosystems. Verh. Internat. Verein. Limnol. 2005, 29, 123-136. [CrossRef]

13. Hering, D.; Platcher, H. Riparian ground beetles (Coleoptera, Carabidae) preying on aquatic invertebrates: A feeding strategy in alpine floodplains. Oecologia 1997, 111, 261-270. [CrossRef]

14. Sabo, I.L.; Power, M.E. River-Watershed Exchange: Effects of Riverine Subsidies on Riparian Lizards and Their Terrestrial Prey. Ecology 2002, 83, 1860-1869. [CrossRef]

15. Paetzold, A.; Schubert, C.J.; Tockner, K. Aquatic-terrestrial linkages along a braided -river: Riparian arthropods feeding on aquatic insects. Ecosystems 2005, 8, 748-759. [CrossRef]

16. Jähnig, S.C.; Brunzel, S.; Gacek, S.; Lorenz, A.W.; Hering, D. Effects of re-braiding measures on hydromorphology, floodplain vegetation, ground beetles and benthic invertebrates in mountain rivers. J. Appl. Ecol. 2009, 46, 406-416. [CrossRef]

17. Bonn, A.; Kleinwächter, M. Microhabitat distribution of spider and ground beetle assemblages (Araneae, Carabidae) on frequently inundated river banks of the River Elbe. Z. Ökolgie Nat. 1999, 8, 109-123. 
18. Manderbach, R.; Hering, D. Typology of riparian ground beetle communities (Coleoptera, Carabidae, Bembidion spec.) in Central Europe and adjacent areas. Arch. Hydrobiol. 2001, 152, 583-608. [CrossRef]

19. Lambeets, K.; Lewylle, I.; Bonte, D.; Maelfait, J.-P. The spider fauna (Aranea) from gravel banks along the Common Meuse: Riparian assemblages and species conservation. Nieuwsbr. Belg. Arachnol. Ver. 2007, 22, $16-30$.

20. Andersen, J.; Hanssen, O. Riparian beetles, a unique, but vulnerable element in the fauna of Fennoscandia. Biodivers. Conserv. 2005, 14, 3497-3524. [CrossRef]

21. Eyre, M.D.; Lott, D.A. Invertebrates of Exposed Riverine Sediments; R\&D Technical Report Wll; National Rivers Authority: Marlow, UK, 1996.

22. Manderbach, R.; Reich, M. Auswirkungen großer Querbauwerke auf die Laufkäferzönosen (Coleoptera, Carabidae) von Umlagerungsstrecken der Oberen Isar. Arch. Hydrobiol. Suppl. 1995, 101, 573-588. [CrossRef]

23. Niemeyer, S.; Reich, M.; Plachter, H. Ground beetle communities (Coleoptera: Carabidae) on the banks of two rivers in the eastern Carpathians, the Ukraine. Verhandl. Gesellsch. Ökol. 1997, 27, 365-372.

24. Marggi, W.A. Faunistik der Sandlaukäfer und Laukäfer der Schweiz (Cicindelidae and Carabidae) Coleoptera. Teil 1/Text. Doc. Faun. Helv. 1992, 13, 463.

25. Trautner, J.; Müller-Motzfeld, G.; Bräunicke, M. Rote Liste der Sandlaufkäfer und und Laukäfer Deutschlands (Coleoptera: Cicindelidae et Carabidae). 2. Fassung. Stand Dezember. Nat. Landsch. 1996, 29, 261-273.

26. Bräunicke, M.; Trautner, J. Die Ahlenläufer-Arten der Bembidion-Untergattungen Bracteon und Odontonium-Verbreitung, Bestandssituation, Habitate und Gefährdung charakteristischer Flussaue-Arten in Deutschland. Angewande Carabidol. Suppl. 1999, 1,79-94.

27. Sadler, J.P.; Bell, D.; Fowles, A. The hydroecological controls and conservation value of beetles on exposed riverine sediments in England and Wales. Biol. Cons. 2004, 118, 41-56. [CrossRef]

28. Dieterich, M. Methods and preliminary results from a study on the habitat functions of the gravel bar interior in alluvial floodplains. Verhandl. Gesellsch. Ökol. 1996, 26, 363-367.

29. Antvogel, H.; Bonn, A. Environmental parameters and microspatial distribution of insects: A case study of carabids in an alluvial forest. Ecography 2001, 24, 470-482. [CrossRef]

30. Adis, J.; Junk, W.J. Terrestrial invertebrates inhabiting lowland river floodplains of Central Amazonia and Central Europe: A review. Freshw. Biol. 2002, 47, 711-731. [CrossRef]

31. Bonn, A.; Hagen, K.; Wohlgemuth-von Reiche, D. The significanse of flood regimes for carabid beetle and spider communities in riparian habitats-a comparison of three major rivers in Germany. River Res. Appl. 2002, 18, 43-64. [CrossRef]

32. Gerisch, M.; Schanowski, A.; Figura, W.; Gerken, B.; Dziock, F.; Henle, K. Carabid beetles (Coleoptera, Carabidae) as indicators of hydrological site conditions in floodplain grasslands. Int. Rev. Hydrobiol. 2006, 91, 326-340. [CrossRef]

33. Gobbi, M.; Fontaneto, D. Biodiversity of ground beetles (Coleoptera: Carabidae) in different habitats of the Italian Po lowland. Agric. Ecosyst. Environ. 2008, 127, 273-276. [CrossRef]

34. Lytle, D.; Poff, N. Adaptation to natural flow regimes. Trends Ecol. Evol. 2004, 19, 94-100. [CrossRef]

35. Bates, A.J.; Sadler, J.P.; Fowles, A.P. Condition-dependent dispersal of a patchily distributed riparian ground beetle in response to disturbance. Oecologia 2006, 150, 50-60. [CrossRef]

36. Lambeets, K.; Vandegehuchte, M.; Maelfait, J.-P.; Bonte, D. Understanding the impact of flooding on trait-displacements and shifts in assemblage structure of predatory arthropods on river banks. J. Anim. Ecol. 2008, 77, 1162-1174. [CrossRef]

37. Paetzold, A.; Yoshimura, C.; Tockner, K. Riparian arthropod responses to flow regulation and river channelization. J. Appl. Ecol. 2008, 45, 894-903. [CrossRef]

38. Lott, D. Ground beetles and rove beetles be associated with temporary ponds in England. Freshw. Forum 2001, 17, 40-53.

39. Gunter, J.; Assmann, T. Restoration ecology meets carabidology: Effects of floodplain restitution on ground beetles (Coleoptera, Carabidae). Biodivers. Conserv. 2005, 14, 1583-1606. [CrossRef]

40. Kirichenko, M.B.; Babko, R.V. Assemblages of ground beetles in the riverside reservoirs of Kyiv. In Ecological State of the Reservoirs of Kyiv; Phytocenter: Kyiv, Ukraine, 2005; pp. 68-74. (In Ukrainian)

41. Brauns, M.; Garcia, X.; Pusch, M.T. Potential effects of water-level fluctuations on littoral invertebrates in lowland lakes. Hydrobiologia 2008, 613, 5-12. [CrossRef] 
42. Šustek, Z. Succession of carabid communities in different types of reed stands in Central Europe. Oltenia. Stud. Comunicări Ştiinţele Nat. 2010, 26, 127-138.

43. Kirichenko, M.B. The Carabid Fauna (Coleoptera, Carabidae) of the River Banks, Lakes Shores and Marshes of the Forest and Forest-Steppe of Eastern Part of the Ukraine. Ph.D. Thesis, Schmalhausen Institute of Zoology NAS of Ukraine, Kiev, Ukraine, 1999. (In Ukrainian).

44. Hůrka, K. Carabidae of the Czech and Slovak Republics; Kabourek: Zlín, Czech Republic, 1996; 565p.

45. Fedorenko, D. Reclassification of World Dyschiriini with a Revision of the Palearctic Fauna (Coleoptea, Carabidae); Pensoft, Sofia, Moscow \& ST: Sofia, Petersburg, 1996; p. 224.

46. Eyre, M.D.; Luff, M.L.; Phillips, D.A. The ground beetles (Coleoptera, Carabidae) of exposed riverine sediments in Scotland and northern England. Biodivers. Conserv. 2001, 10, 403-426. [CrossRef]

47. Jongman, R.H.G.; Ter Braak, C.J.F.; Van Tongeren, O.F.R. Data Analysis in Community and Landscape Ecology; Cambridge Univ. Press: Cambridge, UK, 1995.

48. Beals, M.L. Understanding community structure: A data-driven multivariate approach. Oecologia 2006, 150, 484-495. [CrossRef]

49. Shepard, R.N. The analysis of proximities: Multidimensional scaling with an unknown distance function. I. Psychometrica 1962, 27, 125-140. [CrossRef]

50. Kruskal, J.B. Multidimensional scaling by optimizing goodness of fit to a nonmetric hypothesis. Psychometrica 1964, 29, 1-27. [CrossRef]

51. Cao, Y.; Williams, W.P.; Bark, A.W. Similarity measure bias in river benthic Aufwuchs community analysis. Water Environ. Res. 1997, 69, 95-106. [CrossRef]

52. Mountford, M.D. An index of similarity and its application to classification problems. In Progress in Soil Zoology; Butterworths: London, UK, 1962; pp. 43-50.

53. Faith, D.P.; Minchin, P.R.; Belbin, L. Compositional dissimilarity as a robust measure of ecological distance. Vegetatio 1987, 69, 57-68. [CrossRef]

54. Hwang, C.M.; Yang, M.S.; Hung, W.L. New similarity measures of intuitionistic fuzzy sets based on the Jaccard index with its application to clustering. Int. J. Intell. Syst. 2018, 33, 1672-1688. [CrossRef]

55. Wo, J.; Mou, X.X.; Xu, B.D.; Xue, Y.; Zhang, C.L.; Ren, Y.P. Interannual changes in fish community structure in the northern part of the coastal waters of Jiangsu Province, China in spring. Chin. J. Appl. Ecol. 2018, 29, 285-292. [CrossRef]

56. Oksanen, J.; Blanchet, F.G.; Friendly, M.; Kindt, R.; Legendre, P.; McGlinn, D.; Minchin, P.R.; O’Hara, R.B.; Simpson, G.L.; Solymos, P.; et al. Vegan: Community Ecology Package. R package version 2.4-6. 2018. Available online: https://CRAN.R-project.org/package=vegan (accessed on 13 September 2019).

57. Wickham, H. Ggplot2: Elegant Graphics for Data Analysis; Springer: New York, NY, USA, 2016.

58. Middleton, B. Flood Pulsing and Disturbance Dynamics; John Wiley \& Sons Ltd.: New York, NY, USA, 1999.

59. Junk, W.J. Flood pulsing and linkages between terrestrial, aquatic, and wetland systems. Verh. Internat. Verein. Limnol. 2005, 29, 11-38. [CrossRef]

60. Ward, J.; Tockner, K. Biodiversity: Towards a unifying theme for river ecology. Freshw. Biol. 2001, 46, 807-819. [CrossRef]

61. Gerken, B.; Dörfer, K.; Buschmann, M.; Kamps-Schwob, S.; Berthelmann, J.; Gertenbach, D. Composition and distribution of carabid communities along rivers and ponds in the region of Upper Were (NW/NDS/FRG) with respect to protection and management of a floodplain ecosystem. Reg. Riv. Res Mngm. 1991, 6, 313-320. [CrossRef]

62. Henshall, S.E.; Sadler, J.P.; Hannah, D.M.; Bates, A.J. The role of microhabitat and food availability in determining riparian invertebrate distributions on gravel bars: A habitat manipulation experiment. Ecohydrology 2011, 4, 512-519. [CrossRef]

63. Mazzei, A.; Bonacci, T.; Zetto, T.; Brandmayr, P. La carabidofauna dell'ecotopo fluviale del crati (Cosenza, Italia) (Coleoptera Carabidae). Nat. Sicil. 2010, 34, 187-199.

64. Naiman, R.J.; Décamps, H. The ecology of interfaces: Riparian zones. Ann. Rev. Ecol. Syst. 1997, 28, 621-658. [CrossRef]

65. Ward, J.V.; Tockner, K.; Arscott, D.B.; Claret, C. Riverine landscape diversity. Freshw. Biol. 2002, 47, 517-540. [CrossRef]

66. Andersen, J. Ecomorphological adaptations of Riparian Bembidiini species (Coleoptera: Carabidae). Ecol. Generalis 1985, 11, 41-46. [CrossRef] 
67. Desender, K.; Turin, H. Loss of habitats and changes in the composition of the ground and tiger beetle fauna in four west European countries since 1950 (Coleoptera: Carabidae). Biol. Conserv. 1989, 48, 277-294. [CrossRef]

68. Desender, K. Ecomorphological adaptations of riparian carabid beetles. In Verhandelingen Van Het Symposium 'Invertebraten Van België'; Royal Institute of Natural Sciences: Brussels, Belgium, 1989; pp. 309-314.

69. Desender, K.; Maelfait, J.-P.; Stevens, J.; Allemeersch, L. Loopkevers langs de Grensmaas (carabid beetles along the Common Meuse). Jaarb. LIKONA 1993, 3, 41-49.

70. Van Looy, K.; Vanacker, S.; Jochems, H.; de Blust, G.; Dufrêne, M. Ground beetle habitat templets and riverbank integrity. River Res. Appl. 2005, 21, 1133-1146. [CrossRef]

71. Jachertz, H.; Januschke, K.; Hering, D. The role of large-scale descriptors and morphological status in shaping ground beetle (Carabidae) assemblages of floodplains in Germany. Ecol. Indicat. 2019, 103, 124-133. [CrossRef]

72. Nilsson, C. Conservation management of riparian communities. In Ecological Principles of Nature Conservation; Hansson, L., Ed.; Elsevier: Amsterdam, The Netherlands, 1991; pp. 352-372.

73. Ward, J.V.; Stanford, J.A. Ecological connectivity in alluvial river ecosystems and its disruption by flow regulation. Reg. Rivers Res. Mgmt. 1995, 11, 105-119. [CrossRef]

74. Kirichenko, M.; Babko, R. The spatial population distribution of Omophron limbatum Fabricius 1777 (Coleoptera, Carabidae) in the condition of regulated rivers. Teka Kom. Ochr. Kszt. Srod. Przyr. 2009, 6, 129-137.

75. Januschke, K.; Brunzel, S.; Haase, P.; Hering, D. Effects of stream restorations on riparian mesohabitats, vegetation and carabid beetles. Biodivers. Conserv. 2011, 20, 3147-3164. [CrossRef]

76. Kirichenko, M.; Łagód, G.; Majerek, D.; Franus, M.; Babko, R. The effect of landscape on the diversity in urban green areas. Ecol Chem Eng $S$ 2017, 24, 613-625. [CrossRef]

(C) 2020 by the authors. Licensee MDPI, Basel, Switzerland. This article is an open access article distributed under the terms and conditions of the Creative Commons Attribution (CC BY) license (http://creativecommons.org/licenses/by/4.0/). 